\title{
The occurrence of the Tulip breaking virus in tulips in the northern part of Turkey
}

\author{
Ilyas Deligoz ${ }^{1 *}$, Mehmet Ali Sevik ${ }^{2}$ \\ ${ }^{1}$ Department of Plant Health, Black Sea Agricultural Research Institute, Samsun, Turkey \\ ${ }^{2}$ Department of Plant Protection, Faculty of Agriculture, University of Ondokuz Mayis, Samsun, Turkey
}

\begin{abstract}
The tulip (Tulipa sp.) is one of the most important ornamental bulbous plants, which has been cultivated as a cut-flower, potted, and garden plant, and used for landscaping in Turkey. This study investigated the occurrence of a viral disease in the tulip cultivars Strong Gold, Pretty Woman and Purple Prince that causes striping of the leaves, flames of different colours on the petals and mosaic patterns on the leaves, in Samsun province of Turkey. Surveys of virus-infected tulip plants were carried out in the Middle Black Sea Region of Turkey in 2015-2016. A total of 212 samples were collected from four locations and checked by biological, serological and molecular methods for the presence of the Tulip breaking virus (TBV). TBV was detected in the leaves and flowers by double-antibody sandwich enzyme-linked immunosorbent assays (DAS-ELISA) in the tulip cultivars (15.5\%) tested from Samsun province. TBV infection was found at the highest rate in the cultivar Strong Gold (19.7\%), followed by Pretty Woman (14.1\%) and Purple Prince (12.8\%). The presence of TBV in samples was further confirmed by reverse transcription polymerase chain reaction (RT-PCR) assays. This is the first report on TBV naturally infecting tulips in Samsun province, Turkey.
\end{abstract}

Key words: flower, survey, TBV, tulip, virus

\section{Abbreviations:}

DAS-ELISA - double-antibody sandwich enzyme-linked immunosorbent assay, RT-PCR - reverse transcription polymerase chain reaction, TBV - Tulip breaking virus, TBE - Tris/Borate/EDTA

\section{INTRODUCTION}

The tulip is an important ornamental plant throughout the world and is extremely popular as a cut flower and garden plant in many countries (Rossi and Schuler, 1989). The genus Tulipa is a member of the Liliaceae family and is represented by 17 species, 1 subspecies and 1 variety (19 taxa), two of which are endemic in Turkey (Eker et al., 2014). The tulip originated in Turkey and was introduced into Western Europe in the mid-16 ${ }^{\text {th }}$ century (Garber, 2016). In Turkey, the tulip is an ornamental plant of major economic importance (Turktas et al., 2013).

Tulips and other bulbous ornamental crops are often infected by several viruses (EPPO, 2002; Sochacki, 2013). Among them, the Tulip breaking virus (TBV) is one of the most widely occurring and economically important viruses of tulips (Polder et al., 2010). TBV is a member of the Potyvirus genus. Like other members of that genus, the virions are filamentous, non-enveloped flexuous rods, 680 to $900 \mathrm{~nm}$ long, 12 to $15 \mathrm{~nm}$ in diameter, with helical symmetry, and contain non-segmented single-

*Corresponding author. 
stranded positive-sense RNA (Khan and Dijkstra, 2002). TBV is worldwide in distribution, and its natural hosts are limited to the genera Tulipa and Lilium in the Liliaceae family (van Slogteren, 1971). Typically, the virus infects tulip and lilium species, causing reductions in bulb yields and flower quality (Dekker et al., 1993). TBV produces a range of effects on the colour and forms of the leaves, stems and flowers, which vary depending on the cultivar, the growth stage of the plants and the environmental conditions (EPPO, 2002).

TBV is efficiently transmitted in a nonpersistent manner by several species of aphids, including Myzus persicae, Aphis gossypii, A. fabae, Macrosiphum euphorbiae, Dysaphis tulipae, and Aulacorthum circumflexum (Hammond and Chastagner, 1989). Transmission can also occur by bulb grafting (Lesnaw and Ghabrial, 2000).

In tulips, the symptoms of TBV can vary according to the cultivar and the stage of development of the plants. The virus causes prominent flower colour breaks in red, purple and pink tulip cultivars (van Slogteren, 1971). The symptoms of tulip breaking have been described as streaks, stripes, feathering, or flames of different colours on the petals (Lesnaw and Ghabrial, 2000). The symptoms associated with viral infection, including striping of the leaves, colour-breaking and flames of different colours on the petals, and leaf mosaic have been observed in field-grown tulip plants in the Samsun region.

Despite the importance of the tulip in Turkey, information on viral infections of tulip plants in that country is limited and no specific data on their incidence are available. Therefore, extensive surveys were carried out in the years 2015 and 2016 to study the occurrence of TBV in Samsun province in the northern part of Turkey to gain insights into the epidemiology of the virus.

\section{MATERIALS AND METHODS}

\section{Samples}

A total of 212 samples consisting of leaves (194) and flowers (18) from tulip plants showing viruslike symptoms, such as yellow stripes, dwarfing, deformation, mosaic patterns in the leaves, and colour breaking in the petals, were collected from the cultivars Strong Gold (71), Pretty Woman (71) and Purple Prince (70), commonly grown in Samsun province, in 2015-2016. All the leaf and flower samples collected from the different tulip plants were analyzed by double-antibody sandwich enzyme-linked immunosorbent assays (DASELISA) as soon as possible after collection, while parts of them were stored at $-80^{\circ} \mathrm{C}$ for mechanical inoculations and reverse transcription polymerase chain reaction (RT-PCR) tests.

\section{ELISA tests}

The collected flower and leaf samples were tested for TBV by DAS-ELISA (Clark and Adams, 1977), using specific antibodies (BQ Support, The Netherlands). Briefly, polystyrene microtitre plates (Maxisorb, Nunc, Denmark) were coated, each plate well, with $200 \mu \mathrm{l}$ aliquots of 1:1000 TBV-IgG in a coating buffer. The coating solution was incubated for 2 hours at $37^{\circ} \mathrm{C}$ in the test plates. The samples were prepared from leaves and flowers by homogenizing $1 \mathrm{~g}$ of tissues in an extraction buffer in a ratio of 1:5, and $200 \mu$ aliquots of the extracts were then loaded onto each plate in duplicate wells and incubated overnight at $4^{\circ} \mathrm{C}$. The alkaline phosphatase-conjugate diluting conjugate buffer in a ratio of 1:1000 was then added to the plates $(200 \mu \mathrm{l}$ per each plate well). Absorbance values at $405 \mathrm{~nm}$ were measured using a microtiter plate reader (Sunrise Tecan, Austria) $120 \mathrm{~min}$. after adding the $p$-nitrophenyl phosphate substrate. Samples with absorbance values two times greater than those of healthy samples were considered positive (Sochacki, 2013).

\section{RT-PCR tests}

A one-step RT-PCR method was used for the detection of TBV in the ELISA-positive tulip samples. The RT-PCR reactions were performed using TBV-specific primers (TBV-MC-For1: 5'-TGGAATGTGGGTTATGATGG-3' and TBVMC-Rev1: 5'-GGGTCTTTCAAACCGAGACA-3') (De Kock et al., 2011). The reactions were set up using total RNAs extracted from the infected (ELISA-positive) samples of tulip leaves or flowers according to the standard protocol of the PureLink RNA Mini Kit (Thermo Fisher Scientific, USA).

The RT-PCR assays were carried out using QIAGEN OneStep RT-PCR Kit. The single-step RT-PCR mix consisted of $5 \mu$ of $5 \mathrm{X}$ reaction buffer, $1 \mu \mathrm{l}$ of $10 \mathrm{mM}$ dNTPs, $0.6 \mu \mathrm{M}$ of each primer, $1 \mu \mathrm{l}$ of Qiagen OneStep RT-PCR enzyme mix, 5 units of RNAse inhibitor (Promega), total RNA (0.3-0.5 $\mu \mathrm{g})$ and sterile RNAse-free water to a volume of $25 \mu 1$. Amplification was performed in a PTC200 PCR Thermocycler (Biorad, USA) using the following procedure: reverse transcription $30 \mathrm{~min}$. at $50^{\circ} \mathrm{C}$, followed by denaturation at $95^{\circ} \mathrm{C}$ for 15 min., followed by 36 cycles of $94^{\circ} \mathrm{C}$ for $30 \mathrm{~s}, 52^{\circ} \mathrm{C}$ 
for $30 \mathrm{~s}$ and $72^{\circ} \mathrm{C}$ for $1 \mathrm{~min}$., and a final extension step at $72^{\circ} \mathrm{C}$ for $10 \mathrm{~min}$.; and hold at $4^{\circ} \mathrm{C}$. The PCR products were separated on $1 \%$ ethidium bromidestained agarose gels in a Tris/Borate/EDTA (TBE) buffer visualized with the UVP GelDoc IT system.

\section{Bioassay tests}

For mechanical inoculation, TBV-infected leaf tissue of one sample (ELISA- and PCR-positive) were ground using a mortar in $0.02 \mathrm{M}$ phosphate buffer solution of pH 7.0 (1:10) and mechanically inoculated onto tulips cv. Muscadet, Pretty Woman and Big Smile dusted with carborundum. Four replicates, each containing five plants at their 3-leaf stage, were inoculated for all the cultivars. The inoculated tulip plants were maintained in a plant growth room at $21^{\circ} \mathrm{C}$ and monitored daily for symptoms. The symptoms were recorded periodically for 12 months, and the presence of the virus in the inoculated plants was determined by DAS-ELISA.

\section{RESULTS}

During the 2015 and 2016 growing seasons, infected leaf samples of tulip plants with mosaic and yellow stripe symptoms, and tulip flowers showing colourbreaking in the petals were collected from Samsun province and tested for TBV by DAS-ELISA and RT-PCR. Disease occurrences were visually assessed in the field (Fig. 1) and the identities of the pathogens were confirmed by laboratory testing

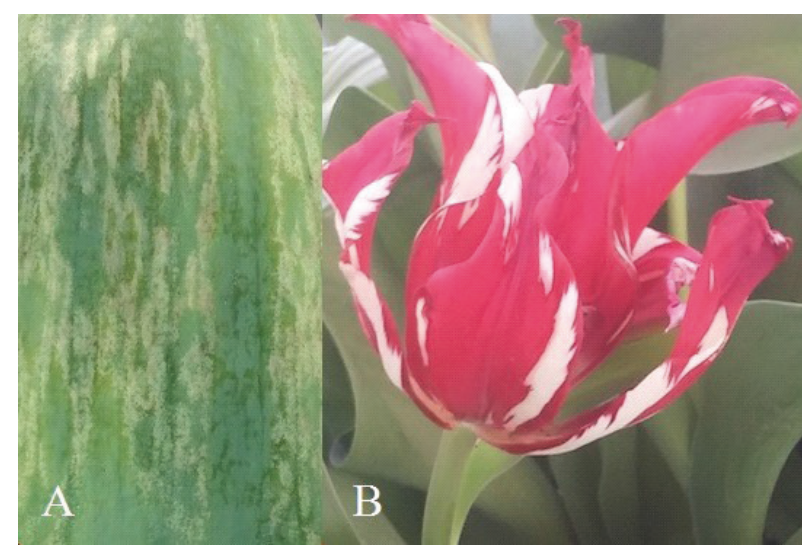

Figure 1. Systemic yellow stripe symptom in a leaf of cv. Strong Gold (A), and flowers of cv. Pretty Woman showing colour-break in the petals (B)

using biological, serological and molecular tests for TBV.

Based on the serological tests, out of the 212 tulip samples tested, $33(15.5 \%)$ were found to be infected with TBV (Tab. 1).

Thirty-three samples (the ELISA-positive ones) were used in the molecular tests and the presence of TBV in all the samples was confirmed by RTPCR. RT-PCR amplification of TBV isolates gave a product of approximately $480 \mathrm{bp}$ with the TBV primer set described above (Fig. 2).

TBV was detected in all the cultivars of the tested tulip samples. TBV was found to be the most prevalent virus in the cultivar Strong Gold (19.7\%), followed by Pretty Woman (14.1\%) and Purple

Table 1. Occurrence of TBV in tulip samples collected in a northern part of Turkey

\begin{tabular}{|c|c|c|c|c|c|c|c|c|}
\hline $\begin{array}{l}\text { Tulip } \\
\text { cultivar }\end{array}$ & $\begin{array}{c}\text { Surveyed } \\
\text { regions }\end{array}$ & $\begin{array}{c}\text { Leaf } \\
\text { samples }\end{array}$ & Infected & $\begin{array}{c}\text { Flower } \\
\text { samples }\end{array}$ & Infected & $\begin{array}{c}\text { Total } \\
\text { collected }\end{array}$ & $\begin{array}{c}\text { Total } \\
\text { infected }\end{array}$ & $\begin{array}{l}\text { TBV } \\
(\%)\end{array}$ \\
\hline \multirow{5}{*}{ Pretty Woman } & Atakum & 16 & 0 & 1 & 1 & 17 & 1 & 5.9 \\
\hline & Carsamba & 12 & 1 & 2 & 2 & 14 & 3 & 21.4 \\
\hline & Ilkadim & 28 & 0 & 4 & 4 & 32 & 4 & 12.5 \\
\hline & Tekkekoy & 6 & 1 & 2 & 1 & 8 & 2 & 25.0 \\
\hline & & 62 & 2 & 9 & 8 & 71 & 10 & 14.1 \\
\hline \multirow{5}{*}{ Purple Prince } & Atakum & 17 & 0 & 1 & 1 & 18 & 1 & 5.6 \\
\hline & Carsamba & 10 & 0 & 4 & 4 & 14 & 4 & 28.6 \\
\hline & Ilkadim & 29 & 1 & 2 & 2 & 31 & 3 & 9.7 \\
\hline & Tekkekoy & 6 & 0 & 1 & 1 & 7 & 1 & 14.3 \\
\hline & & 62 & 1 & 8 & 8 & 70 & 9 & 12.8 \\
\hline \multirow{5}{*}{ Strong Gold } & Atakum & 17 & 2 & 1 & 1 & 18 & 3 & 16.7 \\
\hline & Carsamba & 14 & 4 & 0 & 0 & 14 & 4 & 28.6 \\
\hline & Ilkadim & 31 & 3 & 0 & 0 & 31 & 3 & 9.7 \\
\hline & Tekkekoy & 8 & 4 & 0 & 0 & 8 & 4 & 50.0 \\
\hline & & 70 & 13 & 1 & 1 & 71 & 14 & 19.7 \\
\hline Total & & 194 & 16 & 18 & 17 & 212 & 33 & 15.5 \\
\hline
\end{tabular}




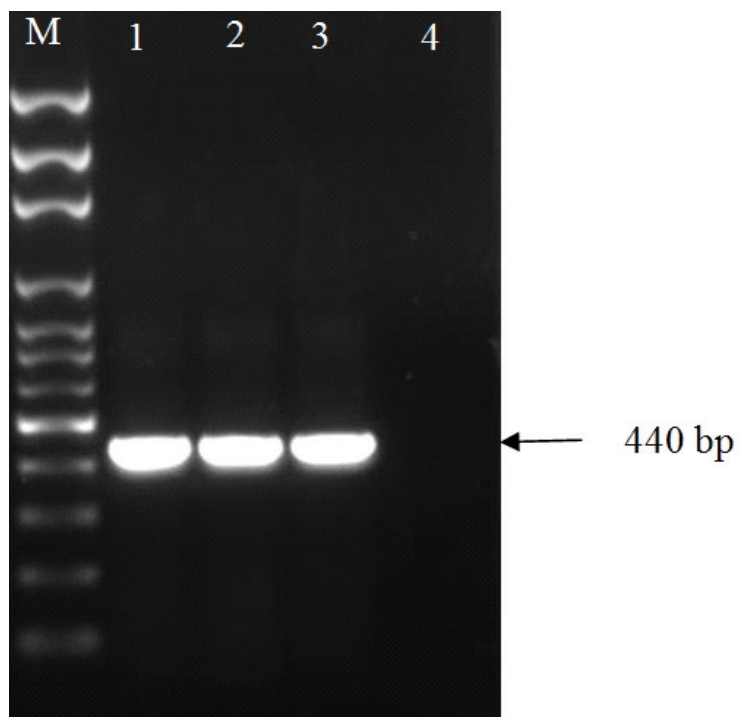

Figure 2. Amplification products obtained for TBV using reverse transcription polymerase chain reaction. M: $100 \mathrm{~kb}$ ladder (Solis Biodyne), Lane 1, 2, 3. TBV ELISA-positive samples, Lane 4: healthy plant

Prince (12.8\%). TBV was detected in 17 samples of the 18 flowers tested, and in 16 samples of the 194 leaves tested in the present study (Tab. 1).

The virus was detected in all the regions surveyed in the current study. The level of TBV infection ranged from 9.4 to $30.4 \%$ of the samples depending on the region. The results of the twoyear survey showed that the highest incidence of TBV occurred at Tekkekoy (30.4\%), followed by Carsamba (26.2\%), Ilkadim (10.6\%), and Atakum (9.4\%).

Pathogenicity assays were also performed by inoculating the virus-positive leaf extract onto indicator plants. Tulips of cv. Muscadet, Pretty Woman and Big Smile were inoculated with leaf extracts containing TBV. Symptom development after inoculation was observed periodically

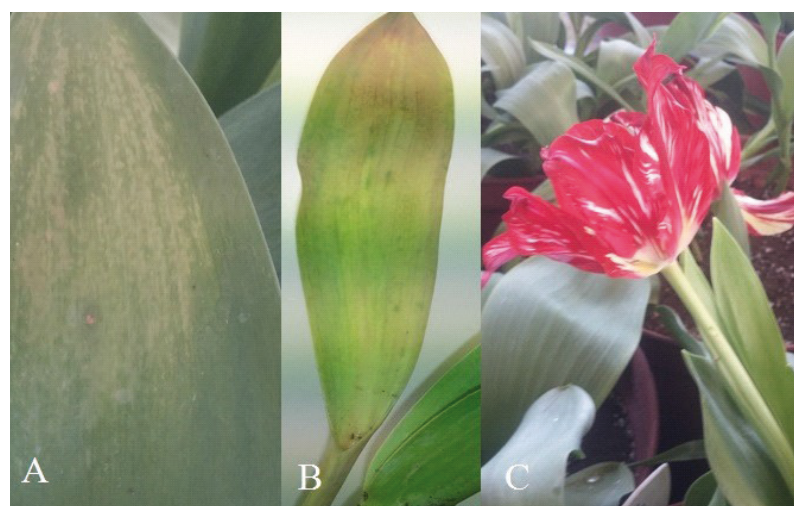

Figure 3. Mosaic symptoms on a TBV-infected leaf of cv. Big Smile (A), systemic chlorosis on a leaf of cv. Muscadet (B), colour-broken flowers of tulip cv. Pretty Woman after inoculation (C) every day for up to twelve months. TBV-infected 'Muscadet' plants showed mild mosaic and chlorosis symptoms, while 'Pretty Woman' and 'Big Smile' showed mosaic symptoms in the leaves. 'Pretty Woman' also showed colour-break symptoms on the petals a year after inoculation (Fig. 3). The symptoms observed on the indicator plants for TBV corresponded to the results of DASELISA and RT-PCR.

\section{DISCUSSION}

Bulbous plants, especially tulips and lilies, lead the cut-flower sector worldwide (Buschman, 2005). Bulbous ornamental crops are infected by several viruses. Among them, TBV is a prevalent and damaging virus of tulips (Mowat, 1995). TBV was first reported on tulips in the Netherlands. Subsequently, it has been reported in all temperate regions where aphid vectors are abundant early in the growing season (EPPO, 2002).

In the present study, tulip leaf and flower samples with suspicious virus symptoms were collected in Samsun province, Turkey, and tested for TBV by DAS-ELISA and RT-PCR. The results presented here demonstrate that TBV was detected in $15.5 \%$ of all the samples of the tulip leaves and flowers collected (Tab. 1). Similarly, TBV had been predominantly detected in Polish tulip plantations (Sochacki, 2013; Sochacki and Treder, 2017). In the present study, TBV was detected in 16 of the 194 leaves tested. Several samples did not react with the TBV antiserum used although the symptoms resembled those caused by viruses. It is possible that nutrient deficiencies (Ozaslan et al., 2006), other viruses, or virus-like agents affect the tulips in Samsun province of Turkey.

The DAS-ELISA tests showed that TBV occurred in all the cultivars from all the regions surveyed, with an incidence ranging very widely among the regions, from a high of $30.4 \%$ at Tekkekoy, followed by $26.2 \%$ at Carsamba, $10.6 \%$ at Ilkadim, to a low of $9.4 \%$ at Atakum. Although the most common virus in tulips is TBV in the Netherlands, the incidence of TBV infection in tulip lots is low and does not exceed 1.9\% (Knippels, 2011). In 2011, about 1.5\% of tulip plants were infected with TBV (van der Vlugt, 2006). However, in the present study, the virus was found relatively common in the samples from Tekkekoy (30.4\%).

TBV causes different types of colour-breaks in tulips depending on the cultivar (Smith et al., 1988). In the current study, flower-related symptoms associated with virus infection, including colour- 
breaks and flames of different colours on the petals, were observed in the tulip plantations surveyed. TBV was detected by DAS-ELISA and RT-PCR in 17 samples of the 18 symptomatic flowers tested in the present study. The infections detected by the serological method correlated well $(87 \%$; 27 of 31 affected plants) with the occurrence of flower colour-break symptoms in the exposed tulips (Hammond and Chastagner, 1989). TBV was detected in the tulip cultivars Strong Gold (yellow), Pretty Woman (red), and Purple Prince (purple), with infection rates of $19.7 \%, 14.1 \%$, and $12.8 \%$, respectively. Similarly, tests had been carried out by Sochacki and Treder (2017) on four tulip cultivars: Hermitage, Pretty Woman, Purple Prince and Strong Gold grown in Poland and those imported from the Netherlands during four forcing seasons between 2010 and 2013. The most frequently detected virus had been TBV (10.1\%). Based on the DAS-ELISA results, TBV infection in Samsun province, Turkey, was determined as the most common in the yellow cultivar Strong Gold. Sochacki (2013) had reported that the yellowflowering cultivar Strong Gold was infected by the virus more often than the bicoloured 'Leen van der Mark'. Overall, in the present study, over $94 \%$ of the flower samples were positive for TBV, while only $8.2 \%$ of the leaf samples were TBV-positive. It is possible that only symptomatic flowers showing mosaic, stripes, or flames of different colours on the petals were collected for the present study.

Biological characterization of the virus was done on different tulip cultivars in order to determine the responses of the host. The TBV-infected plants of the cultivar Big Smile showed mosaic symptoms on the leaves. The 'Pretty Woman' plants showed mosaic patterns on the leaves and colour-breaks on the petals, while those of 'Muscadet' showed mosaic and chlorosis symptoms on the leaves (Fig. 3). These symptoms were similar to those that had been described previously for the virus (Dekker et al., 1993; Brunt et al., 1996; Sochacki, 2013).

In the study, TBV was commonly found affecting tulip plants in Samsun province, Turkey. The spread of the virus was associated with aphid flights, which occurred during the main tulip growing season (Sutton and Garret, 1978). Hammond and Chastagner (1989) had found that TBV transmission was correlated with the presence of aphids and that peak transmission occurred during late April and early May. The virus can also be easily spread when, for example, a healthy flower stem is cut with the same knife used to cut an infected stem, or when bulbs are plugged with virus-infected tissue. Transmission can also occur by bulb grafting (Bos, 1995).

\section{CONCLUSION}

The present paper provides information about the virus infecting tulip plants in Samsun province, Turkey. According to the results of symptom inspections on plants, biological indexing, DASELISA and RT-PCR assays, TBV infections were detected in the tulip cultivars tested. In the current study, TBV was detected both in the leaves and the flowers. TBV was found to be the most prevalent virus in the cultivar Strong Gold, followed by Pretty Woman and Purple Prince. The obtained results showed that TBV was a very common virus in the four tulip-growing regions in Samsun province of Turkey. The virus was commonly found affecting tulip plants in all those regions. It is important to identify the most common virus in a locality to allow development of a comprehensive management strategy. Knowing the potential sources of contamination with the virus has important implications for the prevention and control of outbreaks of TBV. The virus is transmitted by vegetative propagation and insect vectors. Thus, growers must ensure they use healthy bulbs for tulip production.

\section{ACKNOWLEDGEMENT}

We thank the Black Sea Agricultural Research Institute for supporting this research. We would like to thank Sevcan Sari for helping with ELISA tests and Yasemin Izgi Sarac for supplying the tulip cultivars.

\section{AUTHOR CONTRIBUTIONS}

I.D. - surveyed, designed and performed experiments, analyzed data; M.A.S. - gave suggestions, performed experiments, and wrote the paper.

\section{CONFLICT OF INTEREST}

Authors declare no conflict of interest.

\section{REFERENCES}

Bos L., 1995. Viruses of ornamentals: Historical perspectives. In: Virus and Virus-like Diseases of Bulb and Flower Crops. G. Loebenstein, R.H. Lawson and A.A. Brunt (Eds), John Wiley \& Sons/ Balaban, Chichester, UK, 15-22. 
Brunt A.A, Crabtree K., Dallwitz M.J., Gibbs A.J., Watson L., 1996. Viruses of Plants. Descriptions and Lists from the Vide Database. CAB International University Press, Cambridge, UK.

Buschman J.C.M., 2005. Globalisation-flower - flower bulbs - bulb flowers. Acta Hortic. 673, 27-33.

Clark M.F., Adams A.N., 1977. Characteristics of the microplate method of enzyme-linked immunosorbent assay for the detection of plant viruses. J. Gen. Virol. 34, 475-483.

de Kock M.J.D., Stijger C.C.M.M., Pham K.T.K., Lemmers M.E.C., van DAM M., 2011. Non-persistent TBV transmission in correlation to aphid population dynamics in tulip flower bulbs. Acta Hortic. 901, 191-197.

Dekker E.L., Derks A.F., Asjes C.J., Lemmers M.E., Bol J.F., LANGeveld S.A., 1993. Characterization of potyviruses from tulip and lily which cause flower breaking. J. Gen. Virol. 74, 881-887.

Eker I., Babac M.T., Koyuncu M., 2014. Revision of the genus Tulipa L. (Liliaceae) in Turkey. Phytotaxa 157, 1-112.

EPPO, 2002. Production of healthy plants for planting production. Classification scheme for tulip. EPPO Bull. 32, 115-121.

GARber P., 2016. Tulipmania. In: Banking Crises. Perspectives from the New Palgrave Dictionary of Economics. G. Jones (Ed.), Palgrave Macmillan, London, UK, 337-340.

Hammond J., Chastagner G.A., 1989. Field transmission of tulip breaking virus and serologically related potyviruses in tulip. Plant Dis. 73, 331-336.

Khan J.A., Dijkstra J. (Eds), 2002. Plant Viruses as Molecular Pathogens. Food Products Press An imprint of The Haworth Press, New York-LondonOxford, New York.

KNIPPELS P.J.M., 2011. Recent developments in the inspection schemes of flower bulbs. Acta Hortic. 886, 147-151.

LeSnaw J.A., Ghabrial S.A., 2000. Tulip breaking: Past, present, and future. Plant Dis. 84, 1052-1060.

MLCEK J., Rop O., 2011. Fresh edible flowers of ornamental plants - a new source of nutraceutical foods. Trends Food Sci. Tech. 22, 561-569.
Mowat W.P., 1995. Tulip. In: Virus and Virus-like Diseases of Bulb and Flower Crops. G. Loebenstein, R.H. Lawson and A.A. Brunt (Eds), John Wiley \& Sons/Balaban, Chichester, UK, 352-383.

Ozaslan M., Bas B., Aytekin T., Sigirci Z., 2006. Identification of pepper viruses by DAS-ELISA assays in Gaziantep-Turkey. Plant Path. J. 5, 11-14.

Polder G., van der Heijden G.W.A.M., van Doorn J., Clevers J.G.P.W., van Der Schoor R., BALtissen A.H.M.C., 2010. Detection of the tulip breaking virus (TBV) in tulips using optical sensors. Prec. Agric. 11, 397-412.

Rossi R., Schuler S., 1989. Simon \& Schuster's Guide to Bulbs. Simon \& Schuster Ltd, London, UK.

Smith I.M., Dunez J., Phillips D.H., Lelliott R.A., ArCher S.A., 1988. European Handbook of Plant Diseases, Blackwell Scientific Publications, Oxford, UK.

Sochacki D., 2013. The occurrence of the viruses in tulip crops in Poland. J. Hort. Res. 21, 5-9.

Sochacki D., Treder J., 2017. A survey of viruses occurrence in Polish and imported tulip bulbs. Acta Sci. Pol. Hortorum Cultus 16, 105-112.

Sutton J., Garret R.G., 1978. The epidemiology and control of tulip breaking virus in Victoria. Austral. J. Agri. Res. 29, 555-563.

Turktas M., Metin O.K., Bastug B., Ertugrul F., SARAC Y.I., KaYa E., 2013. Molecular phylogenetic analysis of Tulipa (Liliaceae) based on noncoding plastid and nuclear DNA sequences with an emphasis on Turkey. Bot. J. Linn. Soc. 172, 270-279.

VAN DER VlugT R., 2006. Plant viruses in European agriculture: Current problems and future aspects. In: Virus Diseases and Crop Biosecurity, I. Cooper, T. Kuhne and V. Polischuk (Eds), Springer Verlag, The Netherlands, 33-44.

VAN Slogteren D.H.M., 1971. Tulip breaking virus. No: 71. In: CMI/AAB Descriptions of Plant Viruses. A. J. Gibbs, B. D. Harrison and A. F. Murant (Eds), Commonwealth Mycological Institute, Kew, Surrey, England, 4.

Received January 16, 2019; accepted April 25, 2019 